\section{Rutgers To Host ASA}

At the San Francisco Annual Meeting the Board of Directors voted to accept the proposal of Rutgers, The State University of New Jersey, New Brunswick campus, to host the ASA Secretariat for the next five years. Many institutions expressed interest in hosting the Association, and four formal proposals emerged: the University of Florida, the University of North Carolina at Charlotte, the University of Illinois at Urbana-Champaign, and Rutgers. These proposals were circulated to the Board in advance of the Annual Meeting and members were asked by President Berger to rank the proposals. A consensus was reached by the time the Board met, and the University of Illinois and Rutgers were short-listed. Delegations from both of these institutions made oral presentations to the Board and answered questions. The Board, with newly elected members in attendance, then met in camera and voted.

Rutgers is the eighth-oldest institution of higher learning in the US. It was chartered in 1766 as Queen's College. In 1825 the name was changed to Rutgers College in honor of a former trustee and Revolutionary War veteran, Colonel Henry Rutgers. Rutgers became a university in 1924. The state of New Jersey took over Rutgers and all its divisions in 1956. It is the only university in the US to have been a colonial College, a land-grant college, and a state university. Currently the university has an enrollment of 49,000 students, on all three campuses. Graduate and professional students account for $27 \%$ of the enrollment, and women make-up $53 \%$ of the student body. U.S. News \& World Report, in its 1995 "America's Best Values," ranked the Rutgers New Brunswick campus 11th among the 229 institutions it considers national universities. A moving date is not yet fixed, though it is likely to happen this Summer.

\section{ASR Gets New Editorial Team}

The ASA Board has approved a new editorial team for African Studies Review. The group hails from the Five College African Studies Council. Ralph Faulkingham (Massachusetts at Amherst) and Mitzi Goheen (Amherst College) will become the co-editors of the review, while Eugenia Herbert (Mount Holyoke College) will become Book Review Editor, and Samba Gadjigo (Mount Holyoke College) will be the Film Review Editor.

Friend and colleague Mark DeLancey will be stepping down this year as both Editor and Book Review Editor of the African Studies Review. An appeal for members to step forward and take his place was carried in the ASA News. Six proposals were received by the Board. Mustafah Dhada (Clark Atlanta), Toyin Falola (Texas at Austin), and Paul J. Kaiser (Mississippi State) all applied for the Book Review Editor post. York Bradshaw, Nancy Schmidt, and John Hanson (Indiana) proposed a three-person co-editorial team to become Editor, and Franklin Vivekananda (Palo Alto College) also applied to be Editor.

\section{In Memoriam}

Mary Nicol Leakey (1913-1996), palaeoanthropologist, archaeologist, and palaeontologist, passed away peacefully on the 9th of December at the home of her son and daughter-in-law, Richard and Meave. Basic science and hard fieldwork nurtured her and she was fond of telling people that she preferred a tent to a house.

\title{
Members Win!
}

Nancy Gabriel, Nancy Schmidt, and Simon Ottenburg won big in the Do It In June! endowment raffle while others earned book premiums. Note only did Nancy Gabriel, who is also a Life Member, win first prize, but she also won third prize! In fact all of the winners bought multiple tickets. It is a truism in philanthropy that people who support a cause once will likely do so again and again. Little did former President Marty Klein know as he picked the lucky tickets that they would held by such strong supporters of the Association.

All total 129 members bought 542 tickets and they received 54 books as premiums. After expenses were deducted about $\$ 13,500$ remained to credit for the NEH match. If you include contributions received earlier in the year, then we raised some $\$ 22,000$ for the endowment fund.

\section{Glassman Honored with Herskovits Award}

\section{Herskovitz Award}

Committee-Kwame Anthony Appiah

(Chair), Jennifer Widner, Myron Echenberg

Jonathon Glassman's Feasts and Riot: Revelry, Rebellion and Popular Consciousness on the Swahili Coast 1856-1888, (Portsmouth, $\mathrm{NH}$; Heinemann, 1995), achieves something that would until recently have seemed impossible: a full-length monograph of East African history from below in a period before European Conquest. Building on the work of earlier historians of the Swahili coast, the author adds not only his own original research in hitherto neglected German and Zanzibari archives, but also a keen grasp of the work of such scholars as Eric Hobsbawn and E. P. Thompson on "crowds" in Western European social history, to produce remarkable new insights into Swahili society in the second half of the nineteenth century.

At one level, this book is about the festival riots of 1888 , whose development and antecedents it explores elegantly and with a gripping narrative command. Through the prism of the question why these riots occurred, Glassman introduces us to the whole commercial, social, and political world of a portion of the Swahili coast as it made the transition from Omani to European domination. But the book also speaks to broader methodological concerns-concerns that are of great importance across a wide swathe of disciplines and in every part of the world. Glassman's work raises, for example, the question how we can interpret protest and resistance that is not expressed in the language of state politics; how, in short, we are to determine what in the life of crowds-in riots, gossip, or banditry-is political.

But Glassman draws attention, too, to the ways in which subordinated groups can operate in moments of social crisis to claim membership in the dominant-in this case Swahili-political community; and Feasts and Riot thus contributes to our understanding of the role of identities in sustaining hegemony.

Feasts and Riot displays area studies in general, and African area studies, at its best: it shows how the detailed exploration of a local phenomenon, in all its particularity, can illuminate questions of the most general theoretical interest; and it does so in language that combines grace and power, to produce a work that makes compelling reading. 